\title{
The Effect of Hevea Bransiliensis Natural Rubber on Weight Gain and Plasma Cholesterol Concentration of Experimental Rats
}

\author{
${ }^{1}$ Bawa Abubakar, ${ }^{2}$ Njoku O. U., ${ }^{3}$ Salihu Suleiman, ${ }^{2}$ Ozougwu V.E.O., \\ ${ }^{2}$ Agu Chidozie V.And ${ }^{2}$ Okonkwo C. C. \\ ${ }^{I}$ Department Of Preliminary And Remedial Studies, Federal Polytechnic Mubi, Adamawa State, Nigeria. \\ ${ }^{2}$ Department Of Biochemistry, University Of Nigeria, Nsukka, Enugu State Nigeria. \\ ${ }^{3}$ Department Of Chemistry, Federal University Dutse, Jigawa State, Nigeria.
}

\begin{abstract}
The effects of Hevea bransiliensis natural rubber on weight gain and plasma cholesterol concentration of experimental rats were analyzed. Forty albino wister rats of either sex weighing 140-450g were used. The rats were divided into five equal groups marked $A, B, C, D$ and $E$ of eight rats each, and each group was fed on different dietary regime $A, B, C, D$ and $E$ respectively as indicated in tables 1 and 2. Diet $A$, (the control) had no rubber seed oil in the diet, whereas diets $B, C, D$ and $E$ (the experimental) had $2 \%$ refined rubber seed oil, $2 \%$ crude rubber seed oil, $4 \%$ refined rubber seed oil and $4 \%$ crude rubber seed oil by weight incorporated respectively. The results showed a general increase in mean weight with duration of feeding. Group D (4\% refined rubber seed oil incorporated in the diet) showed more rapid increase in mean weights than groups $E$ (4\% crude rubber seed oil) and A (the control no rubber seed oil). The results also indicated a general increase in total and free plasma cholesterol levels of the rats within eight weeks duration of the feeding and fall during the remaining four weeks.
\end{abstract}

Keywords: Hevea bransiliensis, Natural water, Mean weight and Cholesterol.

\section{Introduction}

Natural rubber (Hevea brasiliensis and Fantumia elastica) are two species of rubber tree found in the humid belt of the tropics. The latter species appears to have a more restricted geographic distribution to the lowland rainforest belt of West Africa, whereas Hevea brasiliensis extends in the humid tropical belt from Brazil in the west, through West and Central Africa to India, Malaysia and Indonesia in the East [1].

Natural rubber, (Hevea brasiliensis) was brought under cultivation both in South America and in the India subcontinent in the 19th century principally for its latex which is the main source of rubber. As time went on, due to the large number of seeds produced by the rubber trees during the seed season, some attention was diverted to the investigation of possible uses of this abandon material. By 1919 it has been recognized that the seed of rubber was a potential source of good vegetable oil [2]. The earliest reported works on rubber seed processing and Analysis dates back to early part of the 20th century [3] when a shipment of $269,049 \mathrm{~kg}$ of the seeds was received in U.K from British Malaya for crushing. The seeds, meat and oil were examined for commercial valuation. The yield of the oil from rubber seed depend on several factors some which could easily be controlled [4]. In Nigeria, although para-rubber was introduced into the country before the First World War, no concerted efforts were made to find possible uses for the seeds except as source of seedlings. Unconfirmed reports indicated that dry rubber kernels when crushed were used as soap thickener by certain communities in Edo State. This apparent lack of interest in rubber utilization could be due to lack of information on the quality or composition of the seeds. Recently however, the Rubber Research Institute of Nigeria, as part of its Mandate, initiated work on rubber seed, the kernel, oil and cake with a view to finding or adapting cheap and efficient processing methods that could convert the seeds into the cake and oil, and informing the general public and in particular the industrial community about the possible uses of the oil and cake. Since there are indications that both climatic and edaphic factors may influence the composition of the products [5] complete analysis of the seed, oil and cake became necessary.

Fats and other lipids are essential for the normal functioning of the tissues and organs, as well as of the body as a whole. Thus, in the master tissue of the body, namely the brain, as well as in the spinal cord and associated nervous system, phospholipids, cholesterol, and galactolipids form a large part of the essential portion of the functioning tissue. The lipids are part of the structural elements and these cells could not function without them. Moreover, all cell membranes throughout the body apparently contain lecithin, a phospholipid which is derived from fat. One of the effects of prolonged fat deficiency in rats is the failure of normal kidney functions; this is in all probability to be ascribed to the failure of the body to build up normal cell membranes. Fats also serve as a mechanical protection for nerves and for bony projections. The layer of subcutaneous fat is undoubtedly of considerable importance in maintaining body temperature, particularly because of its function as 
an insulator. Adipose tissue, in addition to connective tissue, acts as a protective covering for organs such as kidney and ovaries, which are frequently imbedded in large amounts of storage fat. Finally, the capability of fat deposits to furnish energy over long periods of time of fasting is another important function of fats and other lipids.

\section{Meterial And Methods}

Forty (40) albino wister rats of either sex weighing 140-450g were used for this analysis. The rats were obtained from the animal house of National Institute of Trypanosomonas Research Centre, Vom in Plateau State, Nigeria. They were kept in stainless steel cages with raised wire floors in a room maintained at $37^{\circ} \mathrm{C}$. The animals were fed for a period of 12 weeks. The rats were divided into five equal groups marked A, B, C, D and $\mathrm{E}$ of eight rats each, and each group was fed on different dietary regime A, B, C, D and E respectively as indicated in tables 1 and 2. Diet A, (the control) has no rubber seed oil in the diet, whereas diets B, C, D and E (the experimental) had $2 \%$ refined rubber seed oil, $2 \%$ crude rubber seed oil, $4 \%$ refined rubber seed oil and $4 \%$ crude rubber seed oil by weight incorporated respectively.

The rats were initially starved for $24 \mathrm{~h}$ before being fed adlibitum with the various diets. Measurement of the liver cholesterol levels were carried out at the beginning of the experiment and subsequently at the end of every four weeks throughout the period of experiment, except the histochemical investigation of the liver that was done initially at the end of three months.

Table 1: Feeding patterns with rubber seed oil incorporated diet

(Njoku, O.U. and Ononogbu, I.C., 1996).

\begin{tabular}{|c|c|c|c|c|c|}
\hline $\begin{array}{l}\text { Group/Treatment of } \\
\text { Rations \% }\end{array}$ & $\mathrm{A}$ & B & $\mathrm{C}$ & $\mathrm{D}$ & $E$ \\
\hline Fish meal & 10 & 10 & 10 & 10 & 10 \\
\hline Ruber seed oil & - & 2 & 2 & 4 & 4 \\
\hline
\end{tabular}

Table 2: Components of rat feed/100g edible portion modified by (Njoku, O.U. and Ononogbu, I.C., 1996).

\begin{tabular}{|l|l|l|l|l|l|l|l|}
\hline & Water (ml) & Protein (gm) & Fat (gm) & $\begin{array}{l}\text { Carbohydrate } \\
(\mathrm{gm})\end{array}$ & Fibre (gm) & Mineral (gm) & Vitamin (gm) \\
\hline Maize flour & 12 & 10 & 4.5 & 71 & 2.0 & 14.5 & 2.48 \\
\hline $\begin{array}{l}\text { Groundnut } \\
\text { cake }\end{array}$ & 6 & 27 & 45 & 17 & 3.0 & 52.5 & 18.05 \\
\hline Fish meal & 20 & 63 & 6.3 & - & - & 3008 & 6.3 \\
\hline $\begin{array}{l}\text { Rubber seed } \\
\text { oil }\end{array}$ & 3.98 & 22.30 & 42.6 & - & 4.20 & 2.9 & - \\
\hline
\end{tabular}

\section{EXTRACTION OF RAT BLOOD PLASMA}

Five rats from each group were anaesthetized with chloroform and blood was withdrawn by cardiac puncture. Just before anesthesia, light was shone on the rats to increase the rate of blood flow into the syringe tubes. $3 \mathrm{ml}$ of blood drawn into EDTA ( 3 drops per $1.0 \mathrm{ml}$ of blood was centrifuged for 10 minutes at $10,000 \mathrm{~g}$ and the plasma (straw coloured liquid) which rises to the top was removed by Pasteur pipette as not to disturb the buffy layer of blood cells. The plasma was stored at $4^{\circ} \mathrm{C}$ until analysis and was analyzed within two days of extraction.

\section{DETERMINATION OF PLASMA TOTAL CHOLESTEROL}

To each test-tube containing $0.2 \mathrm{ml}$ of plasma, $1.8 \mathrm{ml}$ of acetone - ethanol solution was added and centrifuged at $3000 \mathrm{~g}$ for 15 minutes. About $0.4 \mathrm{ml}$ of the clear aliquot was removed and $3 \mathrm{ml}$ of $\mathrm{FeSO}_{4}-\mathrm{acetic}$ acid reagent was added and the mixture was allowed to stand for 10 minutes. The absorbance was read on the spectrophotometer at $490 \mathrm{~nm}$ against a reagent blank.

\section{DETERMINATION OF PLASMA FREE CHOLESTEROL}

To another set of test-tubes containing $0.4 \mathrm{ml}$ of the plasma, $1 \mathrm{ml}$ of digitorin was added and allowed to stand for one hour.

The mixture was centrifuged at $3000 \mathrm{~g}$ for 15 minutes. The supernatant was carefully decanted and the precitate redissolved in $3.0 \mathrm{ml}$ of $\mathrm{FeSO}_{4}$ - acetic acid reagent, $1.0 \mathrm{ml}$ of concentrated sulphuric acid and reaction mixture were allowed to stand for 10 minutes. The content of each test-tube was read at 490nm against a reagent blank. 


\section{Results}

Table 3: The mean weights of the rats.

\begin{tabular}{|l|l|l|l|l|l|l|l|l|l|l|}
\hline Weeks & \multicolumn{9}{l}{$\begin{array}{l}\text { Mean weight difference with respect to the initial weight } \\
\text { in grams) }\end{array}$} & \multicolumn{3}{l}{$\begin{array}{l}\text { Percentage increase in mean weight with respect to the } \\
\text { initial weight }\end{array}$} \\
\hline & $\begin{array}{l}\text { Gp } \\
\text { A }\end{array}$ & $\begin{array}{l}\text { Gp } \\
\text { B }\end{array}$ & $\begin{array}{l}\text { Gp } \\
\text { C }\end{array}$ & $\begin{array}{l}\text { Gp } \\
\text { D }\end{array}$ & $\begin{array}{l}\text { Gp } \\
\text { E }\end{array}$ & $\begin{array}{l}\text { Gp } \\
\text { A }\end{array}$ & $\begin{array}{l}\text { Gp } \\
\text { B }\end{array}$ & $\begin{array}{l}\text { Gp } \\
\text { C }\end{array}$ & $\begin{array}{l}\text { Gp } \\
\text { D }\end{array}$ & $\begin{array}{l}\text { Gp } \\
\text { E }\end{array}$ \\
\hline 0 & - & - & - & - & - & - & - & - & - & - \\
\hline 2 & 25.5 & 20.5 & 22.50 & 21.38 & 20.80 & 15.94 & 18.81 & 13.89 & 14.07 & 17.93 \\
\hline 4 & 56.0 & 46.25 & 50.25 & 46.63 & 48.75 & 35.0 & 42.43 & 31.02 & 30.68 & 42.03 \\
\hline 6 & 96.28 & 84.5 & 80.75 & 79.13 & 82.07 & 60.18 & 77.52 & 49.85 & 52.06 & 70.75 \\
\hline 8 & 152.03 & 130.28 & 124.25 & 120.38 & 122.32 & 95.02 & 119.52 & 76.70 & 79.20 & 105.45 \\
\hline 10 & 212.73 & 185.98 & 184.95 & 179.16 & 176.07 & 132.96 & 170.62 & 114.17 & 117.87 & 151.78 \\
\hline 12 & 287.93 & 248.33 & 250.7 & 242.44 & 236.85 & 179.96 & 218.65 & 154.75 & 159.50 & 204.18 \\
\hline
\end{tabular}

Table 4: Mean plasma total cholesterol concentration $(\mathrm{mg} / 100 \mathrm{ml})$

\begin{tabular}{|l|l|l|l|l|l|}
\hline & Groups & B & C & D & E \\
\hline Weeks & A & $61.0 \pm 1.50$ & $48.0 \pm 1.00$ & $63.0 \pm 3.00$ & $65.0 \pm 2.50$ \\
\hline 0 & $62.5 \pm 2.50$ & $90.0 \pm 1.00$ & $80.0 \pm 5.00$ & $87.5 \pm 2.50$ & $125.0 \pm 5.00$ \\
\hline 8 & $100.0 \pm 1.00$ & $72.5 \pm 7.50$ & $50.0 \pm 1.00$ & $75.0 \pm 5.00$ & $77.5 \pm 2.50$ \\
\hline 12 & $75.0 \pm 5.00$ & $70.0 \pm 5.00$ & $50.00 \pm 2.50$ & $65.0 \pm 2.50$ & $68.0 \pm 5.00$ \\
\hline
\end{tabular}

Table 5: Mean plasma free cholesterol concentration $(\mathrm{mg} / 100 \mathrm{ml})$

\begin{tabular}{|l|l|l|l|l|l|}
\hline & Groups & B & C & D & E \\
\hline Weeks & A & B & $32 . \pm 2.50$ & $42.0 \pm 2.50$ & $37.0 \pm 3.00$ \\
\hline 0 & $35.0 \pm 1.50$ & $32.0 \pm 2.00$ & $59.5 \pm 1.50$ & $45.5 \pm 1.50$ & $66.00 \pm 2.00$ \\
\hline 4 & $59.5 \pm 1.50$ & $53.0 \pm 1.00$ & $42.0 \pm 2.00$ & $36.0 \pm 1.00$ & $48.0 \pm 4.00$ \\
\hline 8 & $45.5 \pm 1.50$ & $49.5 \pm 2.50$ & $37.0 \pm 2.00$ & $46.0 \pm 2.00$ & $38.0 \pm 2.00$ \\
\hline 12 & $39.0 \pm 1.00$ & $35.0 \pm 1.00$ & & \\
\hline
\end{tabular}

\section{Discussion}

Table 3 shows the mean weights of the rats for each group throughout the period of the experiment. The results obtained showed a general increase in mean weight duration of feeding. Group D (4\% refined rubber seed oil incorporated in the diet) showed more rapid increase in mean weights than groups $\mathrm{E}$ (4\% crude rubber seed oil) and A (the control no rubber seed oil). Total cholesterol levels in the plasma of the rats were analyzed during the course of the research and the values were shown in table 4 for the corresponding weeks. The experimental results indicated a general increase in total plasma cholesterol level within eight weeks duration of the feeding and fall during the remaining four weeks. It was however, observed that the increase in plasma cholesterol level was grater in groups E (4\% crude rubber seed oil) and A (the control) than groups D, B and C for the corresponding weeks. The $4 \%$ crude rubber seed oil incorporated into the diet of group E resulted into high increase of plasma cholesterol while the $2 \%$ refined and $4 \%$ efficient rubber seed oil incorporated into the diets of groups B and D rats resulted in the slow increase of their total plasma cholesterol levels as compared to groups $\mathrm{E}$ and A (control) rats. During the course of this research free cholesterol in the plasma were also analyzed as shown in table 5.

The results showed a general increase in plasma free cholesterol during eight weeks of the experiment and falls in the last four weeks of feeding duration. It was, however observed that the increase in plasma free cholesterol level was greater in group E (4\% crude rubber seed oil), A (control), B (2\% refined rubber seed oil) and D (4\% refined rubber seed oil) for the corresponding weeks. Group D animals, on the other hand, showed a minimal increase in plasma free cholesterol level with duration of feeding as shown in table 5. It may be attributed to the percentage of refined rubber seed oil as compared to group E (4\% crude rubber seed oil).

\section{Conclusion}

In conclusion, the results obtained showed a general increase in mean weights of the rats within the duration of feeding. The results also, indicated a general increase in total and free plasma cholesterol levels within eight weeks of duration of the feeding and fall during the remaining four weeks.

\section{References}

[1]. Ansell, Gb. And Hawthorne J.N. (2000). (eds.). Phospholipids: Chemistry, metabolism and function. Elsevier pub. Coy., Amsterdam, Lond. New York.

[2]. Ball, E.R., B.R. clover and W.L. Williams (1965). Dietary induced arterial trhomlosis in mice. Arch. Pathol., 80, 391.

[3]. Bashar, M.A. and Jumat Salimon (2009). Physicochemical Characteristics of Malaysian Rubber (Hevea Brasiliensis) Seed oil European Journal of Scientific Research.

[4]. Bashes, S., Blecker, C., Deroanne, C., Driva, N. E., and Hamadi, A., (2004). Date Seeds: Chemical Composition and Characteristics Profiles of the Lipid Fraction. Food Chemistry 84. Pp. 577-584.

[5]. Njoku, O.U. and Ononogbu, I.C. (1996). Toxicology Studies of the rubber (Hevea brasiliensis) seed oil. West African J. Biol.Sc. 4(2): 135-140. 